\title{
Identification of Open Reading Frames Unique to a Select Agent: Ralstonia solanacearum Race 3 Biovar 2
}

\author{
Dean W. Gabriel, ${ }^{1}$ Caitilyn Allen, ${ }^{2}$ Mark Schell, ${ }^{3,4}$ Timothy P. Denny, ${ }^{4}$ Jean T. Greenberg, ${ }^{5}$ \\ Yong Ping Duan, ${ }^{1}$ Zomary Flores-Cruz, ${ }^{2}$ Qi Huang, ${ }^{6}$ Jennifer M. Clifford, ${ }^{2}$ Gernot Presting, ${ }^{7}$ \\ Enid T. González, ${ }^{2}$ Joseph Reddy, ${ }^{1}$ John Elphinstone, ${ }^{9}$ Jill Swanson, ${ }^{2}$ Jian Yao, ${ }^{2}$ Vincent Mulholland, ${ }^{10}$ \\ Li Liu, ${ }^{11}$ William Farmerie, ${ }^{11}$ Manjeera Patnaikuni, ${ }^{11}$ Botond Balogh, ${ }^{1}$ David Norman, ${ }^{8}$ Anne Alvarez, ${ }^{12}$ \\ Jose A. Castillo, ${ }^{5}$ Jeffrey Jones, ${ }^{1}$ Gerry Saddler, ${ }^{10}$ Theresa Walunas, ${ }^{13}$ Aleksey Zhukov, ${ }^{13}$ and \\ Natalia Mikhailova ${ }^{13}$
}

\begin{abstract}
${ }^{1}$ Plant Pathology Department, University of Florida, Gainesville, U.S.A.; ${ }^{2}$ Department of Plant Pathology, University of Wisconsin, Madison, U.S.A.; ${ }^{3}$ Department of Microbiology, University of Georgia, Athens, U.S.A.; ${ }^{4}$ Department of Plant Pathology, University of Georgia, Athens, U.S.A.; ${ }^{5}$ Department of Molecular Genetics and Cell Biology, University of

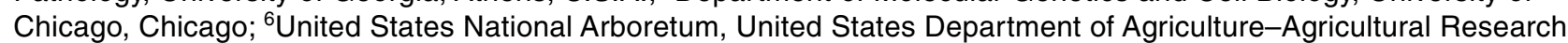
Service, Beltsville, MD, U.S.A.; ${ }^{7}$ Department of Molecular Bioscience and Bioengineering, University of Hawaii, Honolulu, U.S.A.; ${ }^{8}$ Plant Pathology Department, University of Florida, Apopka, U.S.A.; ${ }^{9}$ Plant Environment and Bacteriology, Central Science Laboratory, Sand Hutton, York, U.K.; ${ }^{10}$ Scottish Agriculture and Science Agency, East Craigs, Edinburgh, U.K.; ${ }^{11}$ ICBR, University of Florida, Gainesville, U.S.A.; ${ }^{12}$ Department of Plant Environmental Science, University of Hawaii, Honolulu, U.S.A.; ${ }^{13}$ Integrated Genomics, Chicago, IL, U.S.A.
\end{abstract}

Submitted 11 June 2005. Accepted 20 September 2005.

An 8x draft genome was obtained and annotated for Ralstonia solanacearum race 3 biovar 2 (R3B2) strain UW551, a United States Department of Agriculture Select Agent isolated from geranium. The draft UW551 genome consisted of 80,169 reads resulting in 582 contigs containing 5,925,491 base pairs, with an average $64.5 \%$ GC content. Annotation revealed a predicted 4,454 protein coding open reading frames (ORFs), 43 tRNAs, and 5 rRNAs; 2,793 (or 62\%) of the ORFs had a functional assignment. The UW551 genome was compared with the published genome of $R$. solanacearum race 1 biovar 3 tropical tomato strain GMI1000. The two phylogenetically distinct strains were at least $71 \%$ syntenic in gene organization. Most genes encoding known pathogenicity determinants, including predicted type III secreted effectors, appeared to be common to both strains. A total of 402 unique UW551 ORFs were identified, none of which had a best hit or $>45 \%$ amino acid sequence identity with any $R$. solanacearum predicted protein; 16 had strong $\left(\mathrm{E}<\mathbf{1 0}^{-13}\right)$ best hits to ORFs found in other bacterial plant pathogens. Many of the 402 unique genes were clustered, including 5 found in the $h r p$ region and 38 contiguous, potential prophage genes. Conservation of some UW551 unique genes among R3B2 strains was examined by polymerase chain reaction among a group of 58 strains from different races and biovars, resulting in the identification of genes that may be potentially useful for diagnostic detection and identification of $\mathrm{R3B2}$ strains. One $22-\mathrm{kb}$ region that appears to be present in GMI1000 as a result of horizontal gene transfer is absent from UW551 and encodes enzymes that likely are essential for utilization of the three sugar alcohols that distinguish biovars 3 and 4 from biovars 1 and 2 .

Additional keywords: bacterial wilt, comparative genomics.

Corresponding author: D. W. Gabriel; Telephone: +1.352.392.7877; Fax: +1.352.392.6532; E-mail: gabriel@ biotech.ufl.edu
Ralstonia solanacearum (Smith 1896) Yabuuchi et al. 1996 causes bacterial wilt, one of the most destructive plant diseases worldwide. This soilborne bacterium affects a very wide range of plants in over 50 different families (Hayward 1991) and is the single most important bacterial disease in the tropics (Prior et al. 1998). Economically significant hosts include tomato, tobacco, pepper, peanut, ginger, banana, eucalyptus, and potato. On potato, $R$. solanacearum also causes brown rot, which is characterized by rapid, sometimes unilateral, wilting and yellowing of leaves and generalized stunting. Vascular tissues in the stem and tuber become brown and rot as the disease progresses, and affected plants usually die quickly at temperatures greater than $25^{\circ} \mathrm{C}$. The bacterium is transmitted in latently infected seed potato tubers, as well as by contaminated soil, equipment, and irrigation water (Allen et al. 2001).

$R$. solanacearum is considered a species complex-a heterogeneous group of related but genetically distinct strains (Fegan and Prior 2005; Fegan et al. 1998b). These strains are highly competent for genetic exchange in planta (Bertolla et al. 1999) and show substantial pathogenic variability in host range and aggressiveness (Buddenhagen 1965; Sequeira and Averre 1961). However, the genetic basis for this variation is unknown. Historically, the group was subdivided into "races" based loosely on host range (Buddenhagen and Kelman 1964; Buddenhagen et al. 1962). However, the race structure of $R$. solanacearum is poorly defined and not taxonomically useful (Hayward 1964). The biovars of $R$. solanacearum are better defined than its races and are based on acidification of medium during metabolism of six carbohydrates (maltose, lactose, cellobiose, mannitol, sorbitol, and dulcitol) (Hayward 1964, 1994). An entirely new phylogenetic classification system was proposed recently, consisting of four phylotypes, each further divided into sequevars (Fegan and Prior 2005; Villa et al. 2005).

Strains in each phylotype appear to have evolved separately due to geographical isolation. However, almost regardless of their geographical origin, $R$. solanacearum strains are adapted to survive and cause disease in tropical to warm temperate envi- 
ronments. The one known exception is a phenotypically and genetically homogenous subgroup of phylotype II commonly known as race 3, biovar 2 (R3B2) (Fegan and Prior 2005). These strains, which most often are isolated from potato, apparently originated in the cool Andean highlands and can infect and cause symptoms in potato at temperatures as low as $16^{\circ} \mathrm{C}$ following artificial inoculations (Ciampi and Sequeira 1980; Swanepoel 1990; Thurston 1963). It is unclear whether or not some biovar 1 strains may also have the capacity to cause disease at $16^{\circ} \mathrm{C}$; some biovar 1 isolates grow more rapidly in vitro at $16^{\circ} \mathrm{C}$ than R3B2 isolates (Ciampi and Sequeira 1980). R3B2 strains recently have been spread almost worldwide by movement of infected seed and ware potato (Elphinstone 1996, 2005; Hayward 1991). In temperate European waterways, R3B2 strains can survive for years in the weed host Solanum dulcamara, which sheds large numbers of the pathogen into surface water annually and therefore threatens potato production (Elphinstone 1996; Elphinstone et al. 1998; van Elsas et al. 2000, 2001).

The host range of R3B2 strains once was thought to be limited to potato and a few solanaceous relatives; however, it also can infect multiple other plants, most notably zonal geranium (Pelargonium $\times$ hortorum) (Janse et al. 2004; Tusiime et al. 1998, Williamson et al. 2002). This ornamental occasionally has acted as a carrier of $R$. solanacearum, because cuttings for vegetative propagation are imported to North America and Europe from the highland tropics where the pathogen is endemic (Janse et al. 2004; Kim et al. 2003; Strider et al. 1981; Williamson et al. 2002). R3B2 strain UW551 was isolated in Wisconsin from a wilted geranium grown from a cutting originating in Kenya, but it also is pathogenic on tomato and potato; its biology and behavior have been characterized (Swanson et al. 2005). A key finding was that UW551 was more virulent on potato and tomato than the warm temperature-adapted strain $\mathrm{K} 60$ (phylotype II, race 1 , biovar 1 ) at $24^{\circ} \mathrm{C}$, but the reverse was true at $28^{\circ} \mathrm{C}$. R3B2 strains have not been isolated from potato plants or weeds in North America. R3B2 strains are listed as Select Agents in the United States (Lambert 2002) and are quarantined pathogens in Europe and Canada.

The pathogenic characteristics and cold tolerance of R3B2 strains are poorly understood. In the absence of data, it is impossible to say whether the wide distribution of the biovar 2 genotype is due to i) cold tolerance and chance, ii) specific pathogenic adaptation to potato, iii) specific pathogenic adaptation to weed hosts, iv) novel pathogenicity mechanisms or effectors, or v) a combination of all of these. In addition, the traits traditionally used to identify these strains are either poorly defined (e.g., race) or not predictive of pathogenic specialization (e.g., biovar). A genomics approach to identify the novel components of the R3B2 genome was undertaken in part to gain insight into its biological variation, including host range, pathogenic severity, and ecological fitness. Comparative genomics also is becoming increasingly useful for diagnostic purposes. We report here the draft genome ( $8 \times$ coverage) of $R$. solanacearum R3B2 UW551 and the findings of an international consortium of plant pathologists and bioinformaticians who analyzed the open reading frames (ORFs) and compared them with the complete genome of GMI1000, a phylotype I (race 1, biovar 3) strain isolated from tomato in French Guyana (Salanoubat et al. 2002).

\section{RESULTS AND DISCUSSION}

Draft 8× genomic sequence and annotation of UW551.

In all, 93,580,574 bp were sequenced from 80,169 reads from the pUC18 library of $R$. solanacearum R3B2 UW551 genome, and 582 contigs were assembled using Phred/Phrap/
Consed, resulting in a total of 5,925,491 bp of UW551 assembled sequence. Assuming a genome size similar to GMI1000 $(5.8 \mathrm{Mb}$ ) and a conservative $600 \mathrm{bp}$ per read (based on Phred quality scores $>20), 8.3 \times(=600 \mathrm{bp} \times 80,169 / 5.8 \mathrm{Mb})$ genome coverage of UW551 was achieved. By Poisson statistics (Lander and Waterman 1988), $8 \times$ coverage leaves approximately $1.9 \mathrm{~kb}$ of UW551 DNA missing. The average percent $\mathrm{G}+\mathrm{C}$ content of the assembled contigs was $64.5 \%$; by comparison, the GMI1000 genome is $67 \% \mathrm{G}+\mathrm{C}$. Cosmid pUFJ10 was used to construct a genomic library of UW551. pUFJ10 is a broad host range shuttle vector that was highly stable in UW551, even in planta; the plasmid was still present in $98 \%$ of UW551 colonies reisolated from tomato plants 6 days after inoculation. A total of 768 cosmid clones were curated, end sequenced, and mapped to the contigs. Based on restriction enzyme digests, the average insert size was estimated to be $39.6 \mathrm{~kb}$. Based on cosmid ends that were mapped within contigs, the cosmids were found to have an actual average insert size of $41 \mathrm{~kb}$ (ranging from 21 to $57 \mathrm{~kb}$ ). Based on BAMBUS, a total of 44 contigs would exist after joining contigs using the cosmid library. In all, 99 cosmids had end sequences that did not match existing sequence on the contigs. Six of the original contigs were joined based on additional sequence generated from cosmid sequencing, polymerase chain reaction (PCR) amplifications, or a combination of both.

For each UW551 contig, ORFs were aligned based on BLASTX of the $R$. solanacearum GMI1000 (NC_003295.1) genome using MUMmer/Promer (Kurtz et al. 2004). In all, 4,456 protein coding ORFs, 43 tRNAs, and 5 rRNAs were predicted. Of these, 2,793 (or $62 \%$ of the total) UW551 ORFs were assigned a hypothetical function. Using UW551 and GMI1000 genes paired by BLASTP matches at expected value threshold <1e-5, DAGchainer (Haas et al. 2004) was run with the following settings: gapLength $=1,000$ and DistanceMax $=2,000$. Only regions with at least five gene pairs arranged in the same order were classified as syntenic. DAGchainer was used to process a dataset of 4,014 gene pairs and identified 2,843 genes in 245 syntenic regions, revealing an estimated 2,843/4,014 $=70.8 \%$ synteny between UW551 (phylotype 2) and GMI1000 (phylotype 1). A UW551 ORF (RRSL04794) was found that is 95\% identical to RepA (RSO2238) encoded on the GMI1000 megaplasmid that flanks the replication origin of the megaplasmid. A bipartite genome comprising a megaplasmid and chromosome has been reported for many, if not all, other Ralstonia and Burkholderia strains (Coenye and Vandamme 2003). Together, these observations indicate that the UW551 genome is very likely also bipartite. The $8 \times$ genomic DNA sequences have been deposited at DDBJ/EMBL/GenBank under project accession AAKL00000000. The version described in this article is the first version, AAKL01000000. The genome, annotations, supplementary data, and physical comparisons with GMI1000 are available for viewing and download at the University of Florida's Interdisciplinary Center for Biotechnology Research (UF/ICBR) Genomics Server.

\section{Comparisons of the genomes \\ of $R$. solanacearum strains UW551 and GMI1000.}

Following reciprocal BLASTP searches using the predicted ORFs of UW551 and GMI1000 and an expect value (E) threshold of $<10^{-5}, 3,635$ orthologous pairs (reciprocal best hits) were identified, leaving 821 unique ORFs in UW551 (not found in GMI1000) (Fig. 1A). This was likely an inaccurate estimate resulting from miscalled ORFs in UW551. Therefore an in silico genomic subtraction approach was used: the 4,456 predicted UW551 ORFs were compared with all 5,129 GMI1000 ORFs using BLASTP. A homology index (HI) for 
each UW551-GMI1000 best-hit pair was calculated from the BLAST alignments (discussed below). The UW551 ORFs were split into a set of 3,126 ORFs shared with GMI1000 and a set of 1,330 ORFs absent from GMI1000 using a HI value of 0.45 (Fig. 1A). The UW551-GMI000 best-hit pairs with HI values $>0.45$ have an amino acid sequence identity of $>75 \%$ and match over $75 \%$ of their lengths. To further refine this ORF set and remove miscalled ORFs, the 1,330 UW551 unique ORFs were compared with the genomic DNA sequence of GMI1000 using TBLASTN, and a new HI value was calculated for each UW551-GMI1000 best-hit pair (Fig. 1B). A relative HI cutoff of 0.5 was used and resulted in elimination of approximately 500 miscalled UW551 ORFs that are present in the GMI1000 genome but not in the UW551 predicted proteome.

Approximately 300 of the remaining 775 ORFs were predicted to be transporter components, regulatory genes, and putative membrane proteins which, even after manual evaluation and assignment of these ORFs to a shared or nonshared category relative to GMI1000, seemed largely arbitrary and equivocal. Therefore, a more stringent HI cutoff value of 0.15 was used to generate a set of 470 UW551 ORFs not present in GMI1000. When these were searched using BLASTP against the nonredundant (nr) database, there were only 13 with best hits $\left[\mathrm{E}<10^{-7}\right]$ to any $R$. solanacearum proteins. Most of these were ORFs from other $R$. solanacearum strains (e.g., aidA and $a v r A$ of race 1 biovar 1 strain AW1) or updated genome entries of GMI1000. These and approximately 25 very small $(<30$ residues), suspect (from $<2-\mathrm{kb}$ contigs) or miscalled ORFs were deleted, leaving 402 ORFs, none of which have a best hit with $>45 \%$ amino acid sequence identity to any $R$. solanacearum predicted protein. Each of these ORFs was manually annotated and the results are available online as "UW551 402 unique ORFs" (hereafter referred to as the 402 UW551 gene set) in the "Supplementary Data" section on the UF/ICBR Genomics Server. The majority of these were contained in approximately 25 clusters of at least three contiguous ORFs.

Approximately $160(37 \%)$ of the 402 UW551 gene set had best hits to the nr database with $\mathrm{E}>10^{-2}$ and, hence, appear to be specific to the genome of $R$. solanacearum UW551. Similarly, when this 402 UW551 gene set was compared against 171 bacterial genomes using BLAST (low complexity filter off), 188 ORFs did not have a hit with $\mathrm{E} \leq 10^{-2}$. However, approximately 70 had strong $\left(\mathrm{E}<10^{-25}\right)$ best hits to ORFs in genomes of nonpathogenic soil-inhabiting species in the Burkholderia-Ralstonia family. Of these ORFs, 6 are predicted metal-dependent hydrolases, 7 are predicted oxygenases or oxidases, and 12 others are dehydrogenases and other types of proteins involved in biodegradation. Additionally, two ORFs are predicted to be involved in the synthesis of the energy storage molecule polyhydroxy-alkanoate. These could alter the soil survival properties of UW551 relative to GMI1000. Interestingly, only 2 predicted transport components were found in this Burkholderia-Ralstonia family set and only 7 in the entire 402 UW551 gene set.

Only 16 of the 402 UW551 gene set had strong $\left(\mathrm{E}<10^{-13}\right)$ best hits to ORFs found in other plants pathogens: 1 (RRSL01262) to Xylella fastidiosa; 4 to Erwinia spp. (RRSL00951, RRSL02925, and RRSL00197-00198); 6 to Xanthomonas spp. (RRSL00326, RRSL03413, RRSL03350, RRSL04648, RRSL02221, and RRSL03923); and 10 to Pseudomonas syringae (RRSL01069, RRSL02435, RRSL01829, RRSL00288, RRSL01764, RRSL00059, RRSL01362, RRSL01363, RRSL01828, and RRSL02032). There was no overlap between these sets. The function of these genes is unclear (no P-FAM or COG hits); however, a role in plantmicrobe interactions seems likely.
UW551 unique gene clusters: Prophage and $h r p$ region insertion.

Two clusters of UW551 unique genes are interesting and noteworthy. The most striking is a contiguous 38-gene set (RRSL02400 to RRSL02437), many of which have good similarity to genes of various bacteriophages. This implies that this region may be a prophage or remnant thereof that is unique to UW551, and perhaps many or all R3B2 strains. In fact, the 570-bp sequence which is amplified by the Fegan and associates (1998a) 630 to 631 primers that have been used for PCRbased diagnosis of R3B2 strains is found with $99 \%$ identity within the first gene of this prophage region: RRSL02400 (contig0558.1 37788-377207). Three additional sets of primers, YP205F/R, YP206F/R, and YP230F/R, were designed based on the putative UW551 prophage genes RRSL02425, RRSL02436, and RRSL02414, respectively. All three of these sets of primers amplified all $20 \mathrm{R} 3 \mathrm{~B} 2$ strains tested, and none of the other 36 non-R3B2 $R$. solanacearum strains in Table 1. These primer sets and others from UW551 unique regions that also are conserved among all other R3B2 strains may be useful for diagnostic purposes. However, because the distribution of Ralstonia phage related to this prophage is unknown, a battery of prophage primers may be needed to eliminate false-positive PCR results that may be expected from any individual primer set. No predicted pathogenicity ORFs were identified within the UW551 prophage region.

Another apparently unique region is RRSL3341-3352. This region lacks significant BLAST hits and was not investigated by PCR. Surprisingly, six of the unique ORFs were found in the hrp gene region (discussed below) but are likely not $h r p$ genes.

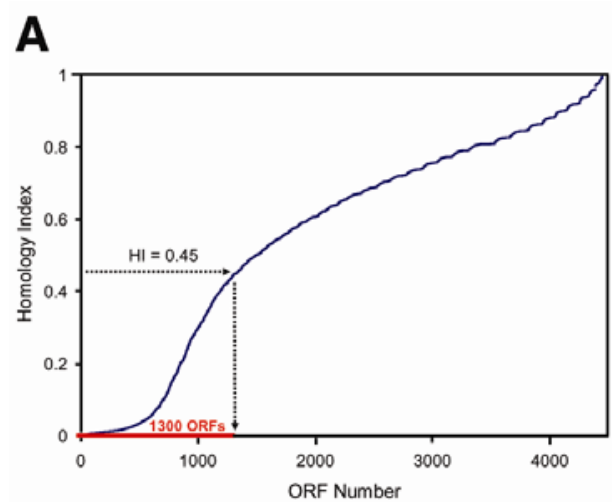

B

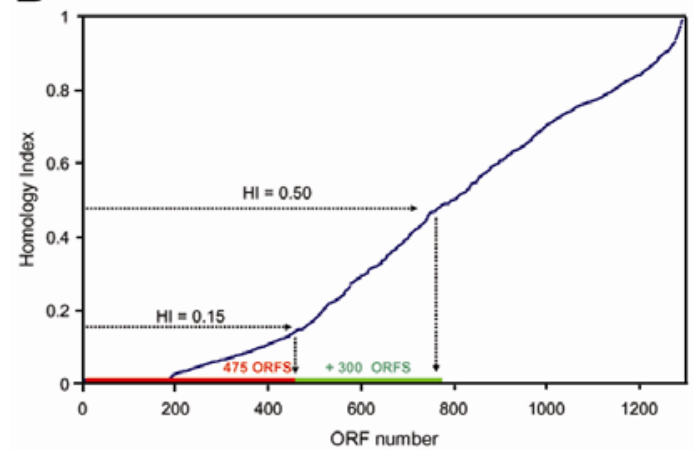

Fig. 1. Criteria used for identification of open reading frames (ORFs) present in UW551 but not in GMI1000. A, Homology index (HI) of all 4,456 predicted ORFs of UW551 compared with all 5,129 predicted ORFs of GMI1000 using BLASTP. B, HI of all 1,330 UW551 unique ORFs from A compared with the genomic DNA sequence of GMI1000 using TBLASTN. 
The UW551 hrp (type III secretion) gene region.

The UW551 hrp region containing the type III secretion (T3S) apparatus genes was organized similarly to GMI1000, except for the insertion of six additional unique ORFs (RRSL02444-7 and RRSL03100-1) plus three translocated ORFs that are present in a different location on the GMI1000 megaplasmid (Fig. 2). However, the six additional UW551 ORFs not found in any other $R$. solanacearum sequence in the nr databases may not be biovar 2 specific. PCR analyses using primers designed to amplify RRSL03101, RRSL02444, RRSL02445, RRSL02446, and RRSL02447 revealed bands of expected size from all five ORFs in several biovar 1 strains, including strains P446, P503, P514, P534, and P622, in addition to all strains tested of R3B2 (not shown). Interestingly, RRSL03101, but not the other four ORFs, was detected in strain P611, a biovar 3 strain. Localization of these PCRdetected ORFs was not determined.

\section{ORFs with a plant-inducible promoter box} and other putative type III effectors.

The consensus nucleotide sequence TTCG-N16-TTCGN32/33-A-N3-T, found in the promoter region of genes that are plant inducible and co-regulated with the hrp genes, was used to identify potential T3S system effectors (Mukaihara et al. 2004). Twenty-five ORFs were identified in UW551 with a canonical plant-inducible promoter (PIP) box and with strong effector signatures (Table 2). Several of these were found in the $h r p$ region (RRSL0499, RRSL03105, and RRSL03109) (Fig. 2). An additional 26 putative effectors were identified based on homology with previously identified ORFs in other plant-pathogenic bacteria (Table 2).

The type III secretome appears highly conserved in Ralstonia spp. Even with the incomplete $8 \times$ draft sequence, UW551 appears to be missing only six or seven potential effectors found in GMI1000, RS1000, or both (Mukaihara et al. 2004). Similarly, only three putative effector genes (RRSL00326, RRSL01019, and RRSL03923) were found in UW551 that were not in GMI1000. Aside from finding gene differences between strains, comparative genomics also is useful for finding genes which may be inactivated in some strains. At least one potential effector, RRSL02855, was discovered that appears to be intact in UW551 but is disrupted in GMI1000 by a transposon. Similarly, RRSL00576 appears intact in UW551 and very similar to an ORF in GMI1000 that may have suffered a frame shift that would truncate an otherwise longer gene. GMI1000 is known to harbor several effector protein families. Interestingly, two of these, called AWR and Gala, respectively (Cunnac et al 2004a), appear to have fewer family members in UW551. This reduction in the size of the protein families may influence the hosts on which UW551 can be a successful pathogen.

\section{Avirulence effector genes and race 3 status.}

$R$. solanacearum currently is divided into five races (Buddenhagen et al. 1962; He et al. 1983), which probably are more appropriately considered as pathovars (Alvarez 2005; Prior and Fegan in press). For example, race 2 preferentially infects triploid banana and other musaceous species, race 4 preferentially infects ginger, and race 5 infects mulberry. Both races 1 and 3 are pathogenic on solanaceous plants like potato and tomato. However, there also is strong evidence of avirulence (avr) gene involvement in limiting $R$. solanacearum host range on tobacco, long considered a differential host, particularly to help distinguish races 1 and 3 (Buddenhagen et al. 1962; Lozano and Sequeira 1970). Race 1 isolates carrying $a v r A$, such as AW1 and GMI1000, elicit rapid cell death that probably indicates a hypersensitive response (HR) associated with plant defense when infiltrated into tobacco leaves. In contrast, race 1 isolates with a transposable element inserted in avrA elicit slow cell death (necrosis) and are pathogenic on tobacco (Carney and Denny 1990; Robertson et al. 2004). Race 3 strains, such as UW551, do not elicit an HR but also are not pathogenic on tobacco and, instead, elicit a mild chlorosis after leaf infiltration (Lozano and Sequeira 1970; Williamson et al. 2002).

Several putative $a v r$ genes are found in UW551 that could limit host range of race 3 on tobacco in a race-specific manner (Table 2). One of these, RRSL01581, is of particular interest because it encodes a predicted 279-amino-acid protein that is $75 \%$ identical to the well-characterized AvrA in strain AW1 (263 amino acids [aa]), and 54\% identical (66\% similar) to the AvrA ortholog RSc0608 (230 aa) in GMI1000. Functionality of these avirulence proteins cannot be predicted from sequence comparisons, because AvrA in GMI1000 is functional despite being only $60 \%$ identical to, and having 33 fewer amino acids (from four locations) than, AvrA in AW1 (Robertson et al. 2004). The additional amino acids present in UW551 AvrA are not due to a transposable element and they may or may not alter AvrA functionality in UW551. UW551 is unique among these three strains because it has an insertion sequence upstream of $a v r A$ and lacks a PIP box. It is possible that the absence of the PIP box reduces avrA expression in UW551 to the point where the HR is not elicited, but not to the point of eliminating avirulence function. Because the race-specific reaction on tobacco is one of the current diagnostic tests for R3B2 strains, the idea that a single

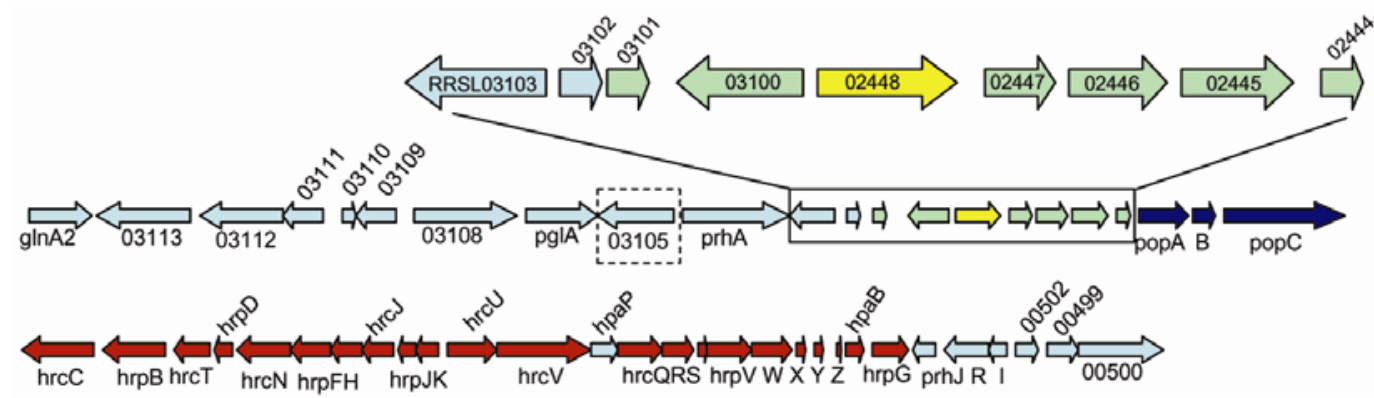

Fig. 2. UW551 hrp cluster. Open reading frames (ORFs) by RRSL number, right to left: RRSL00500, 00499, 00502, 00501, 00503-518, 10002, 00519-20, 00522-25, 10003, 00024, 02441-2448, 03100-6, and 03108-14. Gene colors: red, hrp/hrc; dark blue, pop; yellow, transposase, green, not in GMI1000. Boxed regions indicate genes either not in GMI1000 or organized differently from GMI1000. The organization of the hrp cluster of UW551 is very similar to that of GMI1000, except i) one gene, RRSL03105 (in the dashed-line box) is found in opposite orientation in GMI1000 and ii) nine genes (in the solid-line box) appear to be an insertion in UW551 that is missing in the GMI1000 cluster. Two of the nine genes, RRSL03102 and RRSL03103, correspond to RSp1479 and RSp1478 (over 70\% identity) in GMI1000, but are located at a different site on the megaplasmid, and a third gene, RRSL02448, is a TIS1021transposase that is present in multiple copies on GMI1000. Six genes in the solid line box are not found in GMI1000, but are present in at least some biovar 1 strains in addition to all strains tested of biovar 2 . 
avr gene, possibly RRSL01581, could determine race 3 status requires experimental verification.

\section{Biovar determination genes and status.}

$R$. solanacearum is divided into five biovars based on ability to oxidize the disaccharides cellobiose, lactose, and maltose and utilize the sugar alcohols dulcitol, mannitol, and sorbitol (Hayward 1964, 1994). Biovars 2, 3, and 5 can oxidize the disaccharides; biovars 1 and 4 cannot. Biovars 3 and 4 can utilize the alcohols; biovars 1 and 2 cannot. The GMI1000 (biovar 3 ) genome contains a $22-\mathrm{kb}$ gene cluster encoding $18 \mathrm{ORFs}$ potentially involved in carbohydrate transport and metabolism, including RSc2129 (dalD, D-arabinitol dehydrogenase, pre- dicted to convert mannitol into fructose) and RSc2147 (pols, sorbitol 2-dehydrogenase, predicted to convert sorbitol into fructose and dulcitol into tagatose) (Allenza et al. 1982). The cluster also has RSc2145 (agaZ), the putative tagatose 6-phosphate kinase necessary for a downstream step in the pathway for utilization of dulcitol. This cluster is flanked by tRNA genes, has a percent $\mathrm{G}+\mathrm{C}$ content and codon usage different from the rest of the genome, and is completely absent from the UW551 (biovar 2) contig (0535) carrying the corresponding genomic region. To determine whether these genomic differences between UW551 and GMI1000 generally were applicable to biovars 2 and 3, two sets of primers were designed based on RSc2129 and RSc2147 and were used in PCR tests on all

Table 1. Ralstonia solanacearum strains used to verify conservation of UW551 genes within biovar 2

\begin{tabular}{|c|c|c|c|c|c|c|}
\hline Strain ID & Other ID & Host & Origin & Isolation date & Race & Biovar \\
\hline UW551 & $\ldots$ & Geranium & Kenya & 2003 & 3 & 2 \\
\hline P529 & ATCC33193 & Potato & Egypt & $\ldots$ & 3 & 2 \\
\hline P578 & $\ldots$ & Geranium & Guatemala & 1999 & 3 & 2 \\
\hline P581 & $\ldots$ & Geranium & Guatemala & 1999 & 3 & 2 \\
\hline P582 & $\ldots$ & Geranium & Guatemala & 1999 & 3 & 2 \\
\hline P627 & $\ldots$ & Geranium & Guatemala & 2000 & 3 & 2 \\
\hline P631 & $\ldots$ & Geranium & Guatemala & 2000 & 3 & 2 \\
\hline P632 & $\ldots$ & Geranium & Guatemala & 2000 & 3 & 2 \\
\hline P659 & LMG2294 & Potato & Columbia & $\ldots$ & 3 & 2 \\
\hline P661 & LMG2300 & Potato & Israel & 1954 & 3 & 2 \\
\hline P662 & LMG2306 & Tomato & Portugal & 1960 & 3 & 2 \\
\hline P665 & LMG17139 & Potato & Cyprus & 1963 & 3 & 2 \\
\hline P666 & LMG17140 & Potato & Sweden & 1972 & 3 & 2 \\
\hline P667 & LMG17141 & Potato & Netherlands & 1982 & 3 & 2 \\
\hline P668 & LMG17142 & Potato & England & 1996 & 3 & 2 \\
\hline P675 & $\ldots$ & Geranium & Kenya & 2003 & 3 & 2 \\
\hline P694 & B03162 & Geranium & Costa Rica & 2003 & 3 & 2 \\
\hline P697 & B03165 & Geranium & Costa Rica & 2003 & 3 & 2 \\
\hline P700 & B03168 & Geranium & Costa Rica & 2003 & 3 & 2 \\
\hline P701 & В03169 & Geranium & Costa Rica & 2003 & 3 & 2 \\
\hline P706 & В03194 & Geranium & Costa Rica & 2003 & 3 & 2 \\
\hline P446 & $\ldots$ & Pothos & Costa Rica & 1996 & 1 & 1 \\
\hline P503 & PS1425 & Tomato & Florida & 1996 & 1 & 1 \\
\hline P506 & $\ldots$ & Pothos & Florida & 1996 & 1 & 1 \\
\hline P514 & $\ldots$ & Pothos & Florida & 1996 & 1 & 1 \\
\hline P530 & DPI1541-1 & Tomato & Florida & 1996 & 1 & 1 \\
\hline P532 & $\ldots$ & Tomato & Florida & 1996 & 1 & 1 \\
\hline P534 & $\ldots$ & Tomato & Florida & 1996 & 1 & 1 \\
\hline P541 & $\ldots$ & Potato & Florida & 1997 & 1 & 1 \\
\hline P545 & $\ldots$ & Pothos & Costa Rica & 1997 & 1 & 1 \\
\hline P549 & $\ldots$ & Potato & Florida & 1997 & 1 & 1 \\
\hline P556 & $\ldots$ & & & $\ldots$ & 1 & 3 \\
\hline P557 & $\ldots$ & Anthurium & Costa Rica & 1997 & 1 & 1 \\
\hline P576 & $\ldots$ & Tomato & Florida & 1999 & 1 & 1 \\
\hline P596 & $\ldots$ & Tomato & Florida & 2000 & 1 & 1 \\
\hline P606 & 8217 & Tomato & Guadeloupe & 1985 & 1 & 1 \\
\hline GMI1000 & $\ldots$ & Tomato & Guyana & 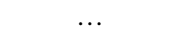 & 1 & 3 \\
\hline P609 & MT1 & Tomato & Martinique & 1986 & 1 & 3 \\
\hline P611 & G34 & Potato & Guadeloupe & 1993 & 1 & 3 \\
\hline P612 & 82GPT117 & Potato & Guadeloupe & 1987 & 1 & 1 \\
\hline P614 & B62 & Eggplant & Guadeloupe & 1993 & 1 & 1 \\
\hline P618 & $99.1119 / 1$ & Anthurium & Guadeloupe & 1999 & 1 & 1 \\
\hline P620 & $99.1120 / 1$ & Anthurium & Guadeloupe & 1999 & 1 & 1 \\
\hline P622 & $99.1121 / 1$ & Anthurium & Guadeloupe & 1999 & 1 & 1 \\
\hline P663 & LMG5839 & Ginger & & & $?$ & 4 \\
\hline P673 & $\ldots$ & Pothos & Florida & 2003 & 1 & 1 \\
\hline P689 & PS121 & Potato & North Carolina & 1945 & 1 & 1 \\
\hline P690 & PS123 & Tomato & North Carolina & 1953 & 1 & 1 \\
\hline P691 & PS124 & tobacco & North Carolina & 1954 & 1 & 1 \\
\hline P692 & PS168-227 & Dahlia & North Carolina & 1960 & 1 & 1 \\
\hline A3381 & UW167, K160 & Banana & Costa Rica & $\ldots$ & 2 & 1 \\
\hline A3908 & KV2.2 & Heliconia & Hawaii & $\ldots$ & 2 & 1 \\
\hline A4493 & S164, UW10, K204 & Heliconia (red) & Costa Rica & $\ldots$ & 2 & 1 \\
\hline A4494 & S200, UW15 & Banana (Cavandish) & Honduras & $\ldots$ & 2 & 1 \\
\hline A4496 & K228, UW35 & Banana, heliconia & Columbia & $\ldots$ & 2 & 1 \\
\hline A4515 & GW1 & Ginger & Hawaii & $\ldots$ & 4 & 4 \\
\hline A5183 & DP-11 & Ginger & Hawaii & $\ldots$ & 4 & 4 \\
\hline
\end{tabular}


58 isolates in Table 1. Both sets of primers amplified DNA fragments exclusively from strains within biovars that can utilize mannitol: biovar 3 (P556, P609, P611, and GMI1000) and biovar 4 (P663, A4515, and A5183). These observations and data together indicate that at least part of the biovar phenotype is the result of horizontal transfer of a few enzyme-encoding genes.

\section{Twin-arginine protein translocation genes.}

The twin-arginine protein translocation (Tat) system is widespread in bacteria, and several pathogenic bacteria require a functional Tat system for virulence (Berks et al. 2003). An R. solanacearum strain K60 mutant lacking TatC (a key structural protein for Tat secretion) is severely attenuated in virulence (E. T. Gonzalez and C. Allen, unpublished data). The TATFIND1.2 algorithm, which identifies likely Tat-secreted proteins based on the presence of a signature N-terminal motif (Dilks et al. 2003), was used to identify 61 putative Tat-secreted proteins in UW551 ("Tat genes" in Supplementary Data on the UF/ICBR Genomics Server). This is nine fewer than found in the GMI1000 genome. Of the 61 putative UW551 Tat-secreted proteins, 42 are found in the GMI1000-predicted Tat secretome. Of the 19 UW551 TAT- secreted proteins, 4 are unique to UW551: RRSL00277, a predicted dipeptide transporter; RRSL01696, a predicted hemin ABC transporter; and RSSL01658 and RRSL03070, both proteins of unknown function. Interestingly, versions of the remaining 15 UW551 Tat-dependent proteins are present in the GMI1000 genome, but they lack the signature N-terminal TAT motif. NosZ and NosL, predicted GMI1000 Tat-secreted proteins absent from the UW551 genome, are part of the dissimilatory nitrate pathway. Their absence from UW551 and from race 1, biovar 1 strains was confirmed by Southern blot (E. T. Gonzalez and C. Allen, unpublished data).

Other pathogenicity loci are conserved: hydrolytic enzymes, type II secretion, efflux pumps, motility and chemotaxis, type IV and fibrillar pili, extracellular polysaccharides, LPS, and known plant-induced ORFs.

Hydrolytic enzymes. $R$. solanacearum produces a consortium of extracellular plant cell-wall-degrading enzymes such as endoglucase (Egl), endo-polygalacturonase (PglA or PehA), and exo-poly- $\alpha$-D-galacturonosidase $(\mathrm{PehB})$; all are known to be required for wild-type virulence of $R$. solanacearum race 1

Table 2. Putative UW551 type 3 effectors

\begin{tabular}{|c|c|c|c|c|c|c|c|}
\hline \multirow[b]{2}{*}{ UW551 I.D. } & \multicolumn{2}{|c|}{ T3S evidence $^{\mathrm{a}}$} & \multicolumn{5}{|c|}{ Similar genes, best hit (blastp values) ${ }^{\mathbf{b}}$} \\
\hline & PIP? & $\mathbf{P}, \mathrm{S}, \mathrm{Q}(\%)$ & UW551 & GMI1000 & RS1000 & Known T3 & Not Ralstonia sp. \\
\hline \multicolumn{8}{|c|}{$\begin{array}{l}\text { Possibly UW551 } \\
\text { specific }\end{array}$} \\
\hline RRSL00326 & Yes & $8 \mathrm{P}, 14 \mathrm{~S}$ & $\ldots$ & $\ldots$ & $\ldots$ & Xcv xopX (6e-15) & Хac, Xcc, Хoo \\
\hline RRSL00576 & Yes & $18 \mathrm{P}, 14 \mathrm{~S}$ & $\ldots$ & $\operatorname{brg} 48(\mathrm{e}-170)^{\mathrm{c}}$ & $\ldots$ & .. & $\ldots$ \\
\hline RRSL01019 & Yes & $12 \mathrm{P}, 4 \mathrm{~S}$ & $\ldots$ & brg5 $(3 e-04)$ & $\ldots$ & $\ldots$ & $\ldots$ \\
\hline RRSL04655 & Yes & $10 \mathrm{P}, 10 \mathrm{~S}$ & $\ldots$ & $\begin{array}{l}\text { RSp1218 } \\
(\mathrm{e}-171)^{\mathrm{d}}\end{array}$ & $\ldots$ & $\ldots$ & $\ldots$ \\
\hline \multicolumn{8}{|c|}{ Ralstonia specific } \\
\hline RRSL00498 & Yes & $8 \mathrm{P}, 12 \mathrm{~S}$ & $\begin{array}{l}\text { RRSL01071 } \\
(2 \mathrm{e}-30)\end{array}$ & $\begin{array}{l}\text { NP_522407 } \\
(0.0)\end{array}$ & $\ldots$ & brg31 AWR (e-23) & $\ldots$ \\
\hline RRSL00508 & Yes & $4 \mathrm{P}, 8 \mathrm{~S}$ & $\begin{array}{l}\text { RRSL00507 } \\
(3 e-16)\end{array}$ & hrpY (2e-41) & & HrpY Pilus & $\ldots$ \\
\hline RRSL00571 & Yes & $14 \mathrm{P}, 18 \mathrm{~S}$ & $\ldots$ & brg43 $(0.0)$ & hpx9 & $\ldots$ & $\ldots$ \\
\hline RRSL01013 & Yes & $14 \mathrm{P}, 08 \mathrm{~S}$ & RRSL0499 (2e-13) & $\operatorname{brg} 33(0.0)$ & $\ldots$ & $\ldots$ & $\ldots$ \\
\hline RRSL01066 & Yes & $12 \mathrm{P}, 14 \mathrm{~S}$ & $\ldots$ & brg37 (3e-129) & $\mathrm{hpx} 21$ & $\ldots$ & $\ldots$ \\
\hline RRSL01260 & Yes & $10 \mathrm{P}, 10 \mathrm{~S}$ & $\cdots$ & $\begin{array}{c}\mathrm{RSc} 2101 \\
(\mathrm{e}-111)\end{array}$ & hpx 18 & $\ldots$ & $\ldots$ \\
\hline RRSL01581 & No & $4 \mathrm{P}, 20 \mathrm{~S}$ & $\ldots$ & avrA (6e-77) & avrA & avrA & $\ldots$ \\
\hline RRSL02442 & $\mathrm{Yes}^{\mathrm{e}}$ & $10 \mathrm{P}, 16 \mathrm{~S}$ & $\ldots$ & popB (e-65) & $\ldots$ & рорВ & $\ldots$ \\
\hline RRSL02443 & $\mathrm{Yes}^{\mathrm{e}}$ & $2 \mathrm{P}, 10 \mathrm{~S}, 18 \mathrm{Q}$ & popA (e-119) & & popA & $\ldots$ & $\ldots$ \\
\hline RRSL03105 & Yes & $12 \mathrm{P}, 6 \mathrm{~S}$ & $\ldots$ & brg34 (e-144) & hpx2 & $\ldots$ & $\ldots$ \\
\hline RRSL03109 & Yes & $10 \mathrm{P}, 6 \mathrm{~S}$ & $\ldots$ & $\begin{array}{l}\text { NP_522443 } \\
\text { (e-142) }\end{array}$ & $\ldots$ & $\ldots$ & $\ldots$ \\
\hline RRSL03113 & Yes & $10 \mathrm{P}, 8 \mathrm{~S}$ & & $\operatorname{brg} 35(0.0)$ & $\ldots$ & $\ldots$ & $\ldots$ \\
\hline RRSL03418 & Yes & $12 \mathrm{P}, 16 \mathrm{~S}$ & $\begin{array}{l}\text { RRSL01071 } \\
(9 \mathrm{e}-45)\end{array}$ & $\operatorname{brg} 31(0.0)$ & & brg31 AWR & $\ldots$ \\
\hline $\begin{array}{l}\text { RRSL04736 } \\
\text { Homologs }^{\mathrm{f}}\end{array}$ & Yes & $14 \mathrm{P}, 10 \mathrm{~S}$ & $\ldots$ & $\operatorname{brg} 44(0.0)$ & hpx26 & $\ldots$ & $\cdots$ \\
\hline RRSL00426 & No & $10 \mathrm{P}, 18 \mathrm{~S}$ & $\begin{array}{l}\text { RRSL00041 } \\
(2 \mathrm{e}-93)^{\mathrm{g}}\end{array}$ & $\operatorname{brg} 19(0.0)$ & & Xcv xopP (2e-57) & Хcc, Хoo, Xac, Bj, Ml \\
\hline RRSL00499 & Yes & $20 \mathrm{P}, 18 \mathrm{~S}$ & RRSL0498 (0.0) & $\operatorname{brg} 32(0.0)$ & hpx4 & brg31 AWR (7e-21) & Хac XAC2009 (8e-07), Xcc \\
\hline RRSL00515 & $\mathrm{Yes}^{\mathrm{e}}$ & $32 \mathrm{P}$ & $\cdots$ & hpaP $(e-100)$ & $\cdots$ & $\cdots$ & $\begin{array}{l}\text { Xoo hpaP }(5 \mathrm{e}-14) \\
\quad(\text { continued on next page })\end{array}$ \\
\hline \multicolumn{8}{|c|}{$\begin{array}{l}\text { T3S = type III secretion, PIP = plant-inducible promoter, and P, S, Q = percent proline, serine, and glutamine, respectively. } \\
\text { UW551, GMI1000, and RS1000 are Ralstonia solanacearum strains. Known T3 = known T3 substrate. Other species abbreviations: Aac, Acidovorax } \\
\text { avenae subsp. citrulli; Ah, Aeromonas hydrophila; Bj, Bradyrhizobium japonicum; Ea, Erwinia amylovora; Eca, E. carotovara subsp. atroseptica; Lpl } \\
\text { Legionella pneumophila str. Lens; Ml, Mesorhizobium loti; Nf, Nocardia farcinica; Pag, Pantoea agglomerans pv. gypsophilae; Pf, Pseudomonas } \\
\text { fluorescens; Ps, P. syringae; Pu, Parachlamydia sp. UWE25; Sf, Sinorhizobium fredii; St, Salmonella typhimurium; Xac, Xanthomonas axonopodis pv } \\
\text { citri; Xag, X. axonopodis pv. glycines; Xcc, X. campestris pv. campestris; Xcv, X. campestris pv. vesicatoria; Xoo, X. oryzae pv. oryzae; Ye, Yersinia }\end{array}$} \\
\hline
\end{tabular}


(Schell 2000), and all also were found in UW551 ("Hydrolytic Enzymes" in Supplementary Data on the UF/ICBR Genomics Server). Other potentially important plant cell-wall-degrading enzymes identified in strain GMI1000, including pectinesterase (Pme), exopolygalacturonase (PehC), a probable exoglucanase $\mathrm{A}$, and a probable family 3 glycosidase, also were found in UW551.

Type II secretion. A gene cluster encoding a type II secretion system is located on the chromosome of UW551 ("Type II Secretion Genes" in Supplementary Data on the UF/ICBR Genomics Server). The gene order is the same in UW551 and GMI1000 (and other $\beta$ subdivision Proteobacteria), but different from Klebsiella and Erwinia spp. and P. aeruginosa. UW551 carries an additional gene, RRSL03989, encoding a putatative major facilitator superfamily transporter, in the cluster that is not found in GMI1000 or other bacteria. Both UW551 and GMI1000 appear to lack a homolog of gspS that is an essential gene in Klebsiella spp. (Sandkvist 2001).

Multidrug efflux pumps. Multidrug efflux pumps can play an important role in microbial pathogenicity, likely by conferring resistance to plant-derived antimicrobials (Barabote et al.
2003). Moreover, R. solanacearum K60 requires two multidrug efflux pump systems for full virulence (D. G. Brown and C. Allen, unpublished data). In all, 47 potential efflux pump genes were found in UW551 by homology with GMI1000 genes - 10 fewer than are annotated in GMI1000and are listed in "Efflux pump genes" in Supplementary Data on the UF/ICBR Genomics Server.

Motility and chemotaxis. Swimming motility, mediated by flagella, contributes significantly to virulence in $R$. solanacearum, specifically during root invasion and early colonization (Tans-Kersten et al. 2001). The flagellar biosynthetic gene clusters are identical in GMI1000 and UW551 in terms of both gene organization and orientation, and the predicted protein sequences are nearly identical ("Flagellar gene cluster" in Supplementary Data on the UF/ICBR Genomics Server). Bacterial taxis, mediated by swimming motility, also contributes to virulence (J. Yao and C. Allen, unpublished data). Organization of the large cluster of taxis genes is largely conserved between UW551 and GMI1000. No chemotaxis receptor genes were unique to UW551 ("Chemotaxis genes" in Supplementary Data on the UF/ICBR Genomics Server).

Table 2. (continued from preceding page)

\begin{tabular}{|c|c|c|c|c|c|c|c|}
\hline \multirow[b]{2}{*}{ UW551 I.D. } & \multicolumn{2}{|c|}{ T3S evidence $^{\mathrm{a}}$} & \multicolumn{5}{|c|}{ Similar genes, best hit (blastp values) ${ }^{b}$} \\
\hline & PIP? & $\mathbf{P}, \mathrm{S}, \mathrm{Q}(\%)$ & UW551 & GMI1000 & RS1000 & Known T3 & Not Ralstonia sp. \\
\hline RRSL00531 & Yes $^{\mathrm{e}}$ & $10 \mathrm{P}, 10 \mathrm{~S}$ & $\begin{array}{l}\text { RRSL00532 } \\
\text { (e-101) }\end{array}$ & RSc1801 (0.0) & hpx 16 & $\ldots$ & Lpl lpl1579 (e-73), Aac, Pu \\
\hline RRSL00532 & Yes & $30 \mathrm{P}, 6 \mathrm{~S}$ & $\begin{array}{l}\text { RRSL00531 } \\
(\mathrm{e}-101)\end{array}$ & $\begin{array}{l}\text { NP_519921 } \\
(\mathrm{e}-121)\end{array}$ & hpx 15 & brg28 Gala (e-68) & Lpl lpl1579 (6e-62), Aac, $\mathrm{Pu}$ \\
\hline RRSL00546 & Yes & $8 \mathrm{P}, 8 \mathrm{~S}$ & RRSL01071 (0.0) & $\begin{array}{l}\text { NP_522585 } \\
(0.0)\end{array}$ & $\ldots$ & brg31 AWR (e-38) & Nf BAD59424 (2e-05) \\
\hline RRSL00703 & Yes & $22 \mathrm{P}, 14 \mathrm{~S}$ & $\begin{array}{l}\text { RRSL01554 } \\
(6 \mathrm{e}-49)\end{array}$ & $\begin{array}{l}\text { NP_519470 } \\
(3 \mathrm{e}-64)\end{array}$ & $\ldots$ & St ssph1 (0.003) & 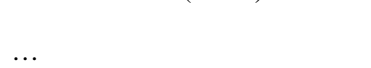 \\
\hline RRSL00752 & Yes & $14 \mathrm{P}, 14 \mathrm{~S}$ & $\begin{array}{l}\text { RRSL00531 } \\
(2 \mathrm{e}-86)\end{array}$ & $\begin{array}{l}\text { NP_521589 } \\
(\mathrm{e}-148)\end{array}$ & $\ldots$ & brg28 Gala (4e-61) & Lpl lp11579 (e-58), Aac, Pu \\
\hline RRSL00852 & Yes & $20 \mathrm{P}, 16 \mathrm{~S}$ & RRSL03923 (e-08) & $\operatorname{brg} 9(0.0)$ & $\ldots$ & Ps hopX1 (6e-21) & Xac, Xcc, Xcv \\
\hline RRSL00926 & Yes & $18 \mathrm{P}, 10 \mathrm{~S}$ & $\ldots$ & brg12 (0.0) & $\ldots$ & Ps hopG1 (e-136) & $\mathrm{Xcc}$ \\
\hline RRSL00947 & Yes & $18 \mathrm{P}, 12 \mathrm{~S}$ & $\ldots$ & brg8 (0.0) & $\ldots$ & Xcv хорВ (e-75) & Ps hopD1 (5e-75), Pag \\
\hline RRSL01016 & Yes & $10 \mathrm{P}, 14 \mathrm{~S}$ & $\ldots$ & brg24 (0.0) & hpx5 & Rs popC (e-24) & Xac hpaF (9e-30), Xoo, Xcv \\
\hline RRSL01017 & Yes & $10 \mathrm{P}$ & RRSL02732 (e-32) & $\operatorname{brg} 1(\mathrm{e}-116)$ & hpx6 & $\ldots$ & $\begin{array}{l}\text { Xag HpaH (3e-33), Xcc, Xac, } \\
\text { Xcv, Xoo }\end{array}$ \\
\hline RRSL01071 & Yes & $14 \mathrm{P}, 18 \mathrm{~S}$ & RRSL00546 (0.0) & $\operatorname{brg} 30(0.0)$ & $\mathrm{hpx} 10$ & brg31 AWR (e-45) & Xoo XOO2543 (5e-08), Xac \\
\hline RRSL01554 & Yes & $10 \mathrm{P}, 22 \mathrm{~S}$ & $\begin{array}{l}\text { RRSL00703 } \\
(6 e-49)\end{array}$ & $\operatorname{brg} 17(0.0)$ & hpx29 & St ssph1 (3e-04) & 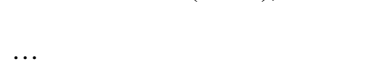 \\
\hline RRSL01561 & Yes & $14 \mathrm{P}, 18 \mathrm{~S}$ & $\begin{array}{l}\text { RRSL02264 } \\
\text { (e-104) }\end{array}$ & $\operatorname{brg} 28(0.0)$ & $\begin{array}{l}\text { hpx } 13, \\
\text { hpx20 }\end{array}$ & brg28 Gala & Lpl lp11579 (4e-80), Aac, Pu \\
\hline RRSL01562 & Yes & $28 \mathrm{P}, 4 \mathrm{~S}$ & $\begin{array}{l}\text { RRSL02264 } \\
(2 \mathrm{e}-71)\end{array}$ & $\operatorname{brg} 29(0.0)$ & hpx 14 & brg28 Gala (5e-58) & Lpl lp11579 (2e-40), Aac, Pu \\
\hline RRSL02213 & Yes & $12 \mathrm{P}, 14 \mathrm{~S}$ & & $\operatorname{brg} 39(0.0)$ & hpx 27 & Ps hopAV1 $(0.0)$ & $\ldots$ \\
\hline RRSL02264 & Yes & $16 \mathrm{P}, 10 \mathrm{~S}$ & $\begin{array}{l}\text { RRSL01561 } \\
(\mathrm{e}-105)\end{array}$ & $\operatorname{brg} 25(0.0)$ & $\mathrm{hpx} 20$ & brg28 Gala (e-108) & Lpl lp11579 (5e-67), Aac \\
\hline RRSL02441 ${ }^{\mathrm{h}}$ & $\mathrm{Yes}^{\mathrm{e}}$ & $16 \mathrm{P}, 12 \mathrm{~S}$ & $\begin{array}{l}\text { RRSL00022 } \\
(\mathrm{e}-132)^{\mathrm{g}}\end{array}$ & popC $(0.0)$ & & Rs popC & Xac, Xag, Xсc, Хoo, Pu, Yp \\
\hline RRSL02573 & Yes & $14 \mathrm{P}, 10 \mathrm{~S}$ & $\ldots$ & brg20 (e-177) & hpx11 & & $\begin{array}{l}\text { Ps hopQ1-1 (2e-99), Xcv XopQ } \\
\text { (3e-99), Хac, Хcc, Хoo }\end{array}$ \\
\hline RRSL02682 & No & $6 \mathrm{P}, 8 \mathrm{~S}, 20 \mathrm{Q}$ & $\ldots$ & brg6 $(0.0)$ & $\cdots$ & Ps hrpW (3e-20) & Xcc, Xac, Ea, Еca \\
\hline RRSL03371 & No & $8 \mathrm{P}, 18 \mathrm{~S}$ & $\cdots$ & $\begin{array}{l}\mathrm{NP} \_522800 \\
(0.0)\end{array}$ & & Xcv xopC (2e-91) & Хoo \\
\hline RRSL03375 & Yes & $6 \mathrm{P}, 14 \mathrm{~S}$ & $\ldots$ & brg15 (0.0) & hpx24 & Ps hopR1 (e-91) & Ps avrE (4e-12), Xcc, Pf \\
\hline RRSL03559 & Yes & $14 \mathrm{P}, 6 \mathrm{~S}$ & $\begin{array}{l}\text { RRSL00426 } \\
(3 e-78)\end{array}$ & $\begin{array}{l}\text { NP_521776 } \\
(0.0)\end{array}$ & $\ldots$ & Xcv xopP (93-42) & Хсc, Хоo, Хас, Bj \\
\hline RRSL03923 & No & $8 \mathrm{P}, 14 \mathrm{~S}$ & $\begin{array}{l}\text { RRSL00852 } \\
(2 \mathrm{e}-08)\end{array}$ & $\begin{array}{l}\text { NP_521488 } \\
(6 \mathrm{e}-09)\end{array}$ & $\ldots$ & Ps hopX1 (7e-04) & $\mathrm{Xcc}$ \\
\hline RRSL04744 & Yes & $6 \mathrm{P}, 12 \mathrm{~S}$ & $\begin{array}{l}\text { RRSL00217 } \\
(8 \mathrm{e}-17)\end{array}$ & $\begin{array}{l}\text { NP_522801 } \\
(0.0)\end{array}$ & $\ldots$ & Ps hopAJ1 (e-116) & Xac, Xcc \\
\hline RRSL04764 & Yes & $10 \mathrm{P}, 20 \mathrm{~S}$ & $\begin{array}{l}\text { RRSL04777 } \\
(\mathrm{e}-148)\end{array}$ & popF1 (e-152) & $\ldots$ & Sf nolX $(0.0)$ & $\begin{array}{c}\text { Xcv hrpF (e-138), Psy hrpK1 } \\
(0.07), \text { Xac, Xag, Xoo, Xcc }\end{array}$ \\
\hline RRSL04777 & Yes & $12 \mathrm{P}, 18 \mathrm{~S}$ & $\begin{array}{l}\text { RRSL04764 } \\
(\mathrm{e}-148)\end{array}$ & popF2 (0.0) & & Sf nolX (e-143) & $\begin{array}{l}\text { Xcv HrpF (e-126), Ye YopB } \\
(0.040) \text {, Xag, Xac, Xcc, Xoo }\end{array}$ \\
\hline RRSL100019 & Yes & $14 \mathrm{P}, 4 \mathrm{~S}$ & $\begin{array}{l}\text { RRSL00426 } \\
(7 \mathrm{e}-15)\end{array}$ & $\begin{array}{l}\text { NP_521721 } \\
\text { (e-94) }\end{array}$ & & Xcc XCC1247 (2e-14) & \\
\hline RRSL10010 & Yes & $2 \mathrm{P}, 12 \mathrm{~S}$ & $\ldots$ & brg13 (e-91) & $\ldots$ & Ps hopH1 (e-44) & $\mathrm{Xcc}$ \\
\hline
\end{tabular}


Retractile (type IV) and potential fibrillar pilus genes. Retractile type IV pili are responsible for bacterial translocation over firm surfaces and contribute significantly to pathogenesis of $R$. solanacearum (Liu et al. 2001). Genes encoding type IV pili were identified in several clusters with similar organization to those found in GMI1000 ("Type IV pili" in Supplementary Data on the UF/ICBR Genomics Server). Fibrillar (Flp) pili are polymeric surface organelles which consist of a parallel array of individual pili. These extracellular structures are thought to facilitate bacterial colonization and survival in some environmental niches through nonspecific tight adherence to solid surfaces, autoaggregation, or biofilm formation (Kachlany et al. 2001). The Flp pili structure and biogenesis are exemplified by the Actinobacillus actinomycetemcomitans system encoded by the ftp-cpa/rcp-tad region. Two large clusters of potential $f l p$ pilus genes were found in UW551, again with similar organization to those in GMI1000 ("Flp pilus genes" in Supplementary Data on the UF/ICBR Genomics Server). These pili have not been experimentally observed, nor has a role in pathogenicity been confirmed in $R$. solanacearum.

Extracellular polysaccharides and XPS genes. Secreted extracellular polysaccharides (EPS) are thought to play a critical role in pathogenesis of $R$. solanacearum (Schell 2000). The UW551 EPS and accessory (XPS) gene cluster was identified and found to be organized similarly to that of GMI1000 ("EPS Locus" in Supplementary Data on the UF/ICBR Genomics Server).
ORFs corresponding to genes shown by in vivo expression technology (IVET) analysis to be upregulated in planta. In a study investigating $R$. solanacearum K60 gene expression in planta using an IVET screen, Brown and Allen (2004) report 153 genes induced during growth in tomato. To date, 135 of the $153 \mathrm{~K} 60$ IVET hits have been analyzed to determine which of these appear to be present in the UW551 draft genome. Of the 135 K60 IVET genes, 113 were identified in UW551 and their function was predicted based on the annotated GMI1000 genome sequence, whereas the remaining 18 did not have any hits in the UW551 contigs ("IVET analysis" in Supplementary Data on the UF/ICBR Genomics Server).

\section{Conclusions.}

Given that $R$. solanacearum is considered to be a species complex with four very different geographical centers of diversity (Asia, America, Africa, and Indonesia), it is not surprising that strains within this complex show substantial pathogenic variation in host range and aggressiveness. What perhaps is surprising is that the genetic basis for this variation is still largely unknown, as is the relative danger posed by R3B2 strains compared with all other $R$. solanacearum strains that are not Select Agents. The $8 \times$ draft UW551 (phylotype II, American, R3B2) genome revealed an unexpected level of $71 \%$ synteny in comparison with the GMI1000 (phylotype I, Asian, R1B3) genome. In addition, all major classes of genes currently known or predicted to be involved in pathogenicity, including plant-degradative enzymes, type III effectors, and

Table 3. Polymerase chain reaction primers used to amplify indicated UW551 or GMI1000 loci

\begin{tabular}{|c|c|}
\hline Amplified locus tag & Primers $\left(5^{\prime}-\mathbf{3}^{\prime}\right)$ \\
\hline \multirow[t]{2}{*}{ RRSL00836 } & YP151F TCCCTGCGACAGCGTCTATG \\
\hline & YP151R CTGCAGCATGAAGGCGAAGT \\
\hline \multirow[t]{2}{*}{ RRSL00888 } & YP152F AGCCCTGCTTCTCCAATGAT \\
\hline & YP152R AAAGAAGACACCCGCAAACA \\
\hline \multirow[t]{2}{*}{ RRSL02425 } & YP205F AGGCGACCTGGGCGACCTCAC \\
\hline & YP205R ATCGGATGCGGGCGGGACGAG \\
\hline \multirow[t]{2}{*}{ RRSL02436 $^{\mathrm{a}}$} & YP206F AGCTCACGGCGCACACCACAC \\
\hline & YP206R GGCGCGTCATGGCTCCACAAC. \\
\hline \multirow[t]{2}{*}{ RRSL00947 (avrPphD) } & YP183F GTGCTGATGCCGCTGCTGA \\
\hline & YP183R GCTCAGGACGATGGCGGAG \\
\hline \multirow[t]{2}{*}{ RRSL02414 $^{\mathrm{a}}$} & YP230F CGTGCGGATGAGCCTGGATGT \\
\hline & YP230R CAGCCACCCGTGCGACTTCAG \\
\hline \multirow[t]{6}{*}{ RRSL03101 ${ }^{\mathrm{b}}$} & YP165F ACGGGCGGTAAGGGAATC \\
\hline & YP165R TGGCTGTGCCGTGGTCTT \\
\hline & YP166F GAGGTCGTCACGGCGTTTT \\
\hline & YP166R TAAACCATTCCACACCAAGGAAGT \\
\hline & YP167F AGGGCCTTTCAGTTCCACTTG \\
\hline & YP167R CGAGCCGTTCGACGAGAA \\
\hline \multirow[t]{2}{*}{ RRSL02444 ${ }^{\mathrm{b}}$} & YP172F CAGGTTCCTTGCACAGAAAGC \\
\hline & YP172R GGTCAAATAATCCGCCTTCGT \\
\hline \multirow[t]{6}{*}{ RRSL02445 } & YP173F GCCAAGGACATCGTGAAACTC \\
\hline & YP173R TCTGCGAAGCCTTGAGGATAG \\
\hline & YP174F ACCGCGGCCAGTTGCTA \\
\hline & YP174R CCATGCCGTTATCGGAAGTG \\
\hline & YP175F AGCGCAAGCTGATCTCTATCTTC \\
\hline & YP175R GGCGGCCGTATTTGTTCA \\
\hline \multirow[t]{2}{*}{ RRSL02446 } & YP176F GTGTATGACATGCAAGCGTTGA \\
\hline & YP176R GCACGAAGACCCAGGTGAAT \\
\hline \multirow[t]{2}{*}{ RRSL02447 } & YP177F ATGTTCAACAAGACTGCGATGCT \\
\hline & YP177R CGAGCTGACCGAGAGTGATG \\
\hline \multirow[t]{4}{*}{ RRSL01249-51 } & YP184F AACAACTACCGCAGCACCATT \\
\hline & YP184R TACCGCCTCCATAAACTCCAC \\
\hline & YP185F CCCCAACAAAAАCТАСТССАC \\
\hline & YP185R GCCGACTGAAATGAAGACCAA \\
\hline \multirow[t]{2}{*}{ RSc2129 D-arabinitol dehydrogenase } & YP190F CCGACGCTCGCCGAATGCTTT \\
\hline & YP190R CGCACGCACCGCCTGGACAAG \\
\hline \multirow[t]{2}{*}{ RSc2147 L-iditol 2-dehydrogenase } & YP125F CGGCATCGACATCCTGTTCAA \\
\hline & YP125R CCTCACCGACCAGACGCTTCT \\
\hline
\end{tabular}

${ }^{a}$ Loci found in UW551 prophage.

${ }^{\mathrm{b}}$ Loci found among UW551 additional open reading frames in the hrp cluster. 
some additional ORFs known to be upregulated in plants, were highly conserved. Genomic comparisons immediately revealed the biovar determining alcohol oxidation gene differences (they were absent or present, likely due to horizontal gene transfer) and interesting variations in avrA that may affect race. Among the 402 genes present in UW551 but absent in GMI1000, few appeared to be involved in pathogenicity and none obviously involved in cold tolerance. Therefore, pathogenic and cold adaptation variability within the species may be determined by regulatory genes, genes of unknown function, or the genetic variation found among conserved genes. Physically, the most obvious difference between the compared genomes was the presence of a cluster of 38 probable prophage genes only in UW551. PCR analyses revealed that this cluster of genes were present in all R3B2 strains tested from a wide variety of geographical sources. These data confirm that R3B2 strains are highly clonal and that UW551 is representative of the group.

\section{MATERIALS AND METHODS}

\section{Strain handling and curation.}

Strain UW551 was isolated from a diseased geranium originating in Naivasha, Kenya and typed as R3B2 (Swanson et al. 2005). Once it was determined to be a Select Agent, it was maintained in U.S. labs under strict quarantine conditions and permits established by the United States Department of Agriculture-APHIS. UW551 was confirmed by two independent labs to be pathogenic on geranium, tomato, and potato and to be nonpathogenic to tobacco. The strain then was sent to four different labs for curation. Total DNA was extracted using standard methods.

\section{Genomic DNA preparation and sequencing.}

Total DNA from UW551 (220 $\mu$ g high molecular weight) was suspended in water, determined to be free of all culturable bacteria, and sent to SeqWright (Houston, TX) for sequencing. The DNA was sheared by SeqWright into 1- to 3-kb fragments and subcloned into pUC18, after which 38,000 randomly selected clones were single pass sequenced using $\mathrm{M} 13 \mathrm{~F}$ and M13R primers. Theoretically, 76,000 $(38,000 \times 2)$ sequencing reads of $600 \mathrm{bp}$ each are needed by Poisson calculation (Landere and Waterman 1988) to result in $8 \times$ coverage of an assumed 5.8-Mb genome (based on GMI1000). The probability of a base not being sequenced is $e^{-c}$, where $c=L N / G$, where $L=$ read length, $N=$ number of reads, and $G$ is the target sequence length (Lander and Waterman 1988). Initial assembly was carried out by SeqWright using the Phred/Phrap/Consed package (Gordon et al. 1998).

\section{Cosmid vector, DNA preparation, and sequencing.}

A 1.2-kb fragment conferring resistance to kanamycin was removed from pKLN66 (Newman et al. 2003) using XmaI and $B a m \mathrm{HI}$, blunt ended using Klenow polymerase, and ligated to NcoI and BfrBI digested and blunt-ended vector pBBR1MCS5 (Kovach et al. 1994). The resultant plasmid, pUFJ05, confers resistance to gentamycin and kanamycin. The 331-bp cos region from pHC79 (Hohn and Collins 1980) was amplified by PCR, cloned in pGEM-T Easy (Promega Corp., Madison, WI, U.S.A.), then sequenced and recloned into pUFJ05 using BstBI and AgeI, forming the 6,015-bp cosmid pUFJ10.

pUFJ10 was digested separately with EcoRI and XbaI, treated with alkaline phosphatase, and then cut with BamHI. Total DNA of UW551 was partially digested with Sau3A1 and was separated on $0.8 \%$ low-melting agarose. High molecular weight Sau3A1-digested DNA was extracted from the agarose gel using GELase (Epicentre, Madison, WI, U.S.A.) according to the manufacturer's protocol and ligated to the pretreated cosmid pUFJ10. Cosmids were packaged using Gigapack III Gold packaging extract (Stratagene, La Jolla, CA, U.S.A.) and introduced into Escherichia coli $\mathrm{DH} 5 \alpha$ via transfection. Individual colonies were selected on Luria-Bertani (LB) agar medium containing kanamycin at $25 \mu \mathrm{g} \mathrm{ml}^{-1}$ and stored (in LB broth with $14 \%$ glycerol + kanamycin) in 96-well, flat-bottom plates. Cosmid DNA of 18 randomly picked colonies was extracted using alkaline lysis (Sambrook and Russell 2001) and digested with EcoRI. The resultant DNA fragments were separated by agarose gel electrophoresis and examined for size and randomness of the inserts. In all, 768 cosmid clones were end sequenced using vector-based primers (T7 and M13R).

\section{Genome annotation.}

Automated annotation was performed by Integrated Genomics (IG; Chicago) to identify ORFs, rRNA, and tRNA encoding regions and, where possible, assign function. Functional assignments were made using proprietary ERGO software and information derived from IG's nr protein database containing more than 2 million sequences (Overbeek et al. 2003).

\section{In silico genomic subtraction procedure.}

All predicted ORFs of $R$. solanacearum UW551 were compared with all predicted ORFs of $R$. solanacearum GMI1000 (GenBank accession NC_003295.1) using BLASTP (ver. 2.1; web interface) with the following settings: low-complexity filter, off; E-value cutoff, $100 ;-\mathrm{b}, 1 ;-\mathrm{v}, 1$. The pairwise, nongraphical view output was saved and parsed with flanders3.pl (M. Schell, unpublished data) using a homology index cutoff value of 0.45 . The homology index is calculated as (amino acid identity between query and hit) ${ }^{2} \times$ (hit length/query length) $\times$ (alignment length/query length). Because some UW551 ORFs probably were miscalled, the UW551 unique ORFs also were compared with the genomic DNA sequence of GMI1000 using TBLASTN with the following settings: low-complexity filter, on; E-value cutoff, $10^{-11},-\mathrm{v}, 1 ;-\mathrm{b}, 1$. The TBLASTN output in hit-table format was saved and parsed with flanders3.pl using a homology index value of 0.15 . For TBLASTN, the homology index is calculated as above without factoring in the hit length.

\section{Web interface and distributed manual annotation.}

A secure web-based interface was set up and maintained by the UF/ICBR Genomics Services laboratory, which also curated all original DNA sequencing reads, assembly edits, ORF calls, and ORF edits. The web site was interactive, allowing all participants in the project access to sequence information and updates in real time. All ORFs that appeared to be found in UW551 but missing in GMI1000 were annotated manually. These ORFs were compared against the GenBank nr database using BLAST and PFAM and, also run individually against 171 publicly available completely sequenced microbial genomes, including 9 eukaryotes, 144 eubacteria, and 18 archaebacteria ("UW551 individual BLASTS" in Supplementary Data on the UF/ICBR Genomics Server). This BLAST information was used in the annotation of the 475 UW551 unique ORFs. In addition to the UW551-unique ORFs, particular attention was given to ORFs that likely were involved in pathogenicity or cold tolerance, including i) the HR and pathogenicity (hrp) or T3S gene region, ii) ORFs with a PIP consensus sequence (PIP box), iii) ORFs encoding predicted hydrolytic enzymes, iv) ORFs encoding type II secretion genes, v) ORFs corresponding to genes known by IVET analysis to be upregulated in planta, vi) flagellar genes, vii) type IV and tight adherence pilus genes, viii) efflux pump genes, ix) Tat substrate genes, and $\mathrm{x}$ ) EPS genes. 


\section{T3S substrate candidates.}

The UW551 genome first was searched for all sequences matching the longer consensus PIP box sequence TTCG-N16TTCG-N32/33-A-N3-T as well as the shorter consensus sequence TTCGC-N15-TTCGC (Mukaihara et al. 2004). The nearest potential ORFs then were examined for effector signatures at the $\mathrm{N}$ terminus of the predicted proteins. Specifically, the first 50 aa were examined for percent proline $(\mathrm{P})$ and percent serine $(\mathrm{S})$. In many species, effectors have percent $\mathrm{P}$ or percent $\mathrm{S}$ biases in their $\mathrm{N}$ termini (Greenberg and Vinatzer 2003). For this analysis, known and candidate effectors from GMI1000 were evaluated to derive the effector amino acid bias rules for $R$. solanacearum effectors (data not shown). A candidate was accepted if percent $P$ or percent $S$ was $\geq 12 \%$ or if percent $P+S \geq 16 \%$. In rare cases, a candidate was accepted if glutamine $(\mathrm{Q})$ was $\geq 12 \%$ and the protein was related to a known effector. Candidate proteins were excluded if, when Blasted to the general database, the $\mathrm{N}$ terminus aligned with proteins from organisms that lacked a T3S. Proteins with potential type II secretion (sec) signal motif were not excluded because some proteins that have a sec signal are known to have orthologs that are type III-secreted (Vinatzer et al. in press).

In addition to ORFs identified using a PIP box motif, the UW551 database was searched for orthologs encoding known T3S substrates from P. syringae; Ralstonia, Xanthomonas, and Erwinia spp.; and encoding Ralstonia proteins known or highly suspected to be secreted, such as hpx (hrpB-dependent expression) (Mukaihara et al. 2004) and $b r g$ ( $h r p B$ regulated) (Cunnac et al. 2004b). These proteins also were examined for effector signatures. Contigs that were effector-rich were more closely examined for genes adjacent to putative effectors or genes in the same operon as an effector.

\section{PCR evaluation of ORFs.}

PCR primers were designed to amplify fragments from 14 ORFs of particular interest and used to determine if these ORFs were generally conserved within R3B2 strains and not found in other biovars or if they were simply specific to strain UW551. Primers used for each of these ORFs are listed in Table 3. These primers were used to amplify DNA from 21 R3B2 strains and 37 strains from a variety of other races and biovars of $R$. solanacearum (Table 1). PCR reactions were performed with either purified DNA or directly from cells at annealing temperatures based on the primers' melting point using Taq polymerase from Invitrogen (San Diego, CA, U.S.A.) and buffer D from EPICENTRE (Madison, WI, U.S.A.).

\section{ACKNOWLEDGMENTS}

This project was supported by the United States Department of Agriculture (USDA)-APHIS-CPHST under contract 53-6395-3-C067 and Cooperative Agreement 04-8100-0946-CA to D. W. Gabriel. J. A. Castillo and J. T. Greenberg were supported by a National Science Foundation grant from the Plant Genome panel. C. Allen was supported by a USDA Floral and Nursery Industry Task Force Specific Cooperative Agreement.

\section{LITERATURE CITED}

Allen, C., Kelman, A., and French, E. R. 2001. Brown rot of potatoes. Pages 11-13 in: Compendium of Potato Diseases. W. R. Stevenson, R. Loria, G. D. Franc, and D. P. Weingartner, eds. American Phytopathological Society Press, St. Paul, MN, U.S.A.

Allenza, P., Lee, Y. N., and Lessie, T. G. 1982. Enzymes related to fructose utilization in Pseudomonas cepacia. J. Bacteriol. 150:1348-1356.

Alvarez, A. 2005. Diversity and diagnosis of Ralstonia solanacearum. Pages 437-447 in: Bacterial Wilt: The Disease and the Ralstonia solanacearum Species Complex. C. Allen, P. Prior, and A. C. Hayward, eds. American Phytopathological Society Press, St. Paul, MN, U.S.A.

Barabote, R. D., Johnson, O. L., Zetina, E., San Francisco, S. K., Fralick,
J. A., and San Francisco, M. J. 2003. Erwinia chrysanthemi tolC is involved in resistance to antimicrobial plant chemicals and is essential for phytopathogenesis. J. Bacteriol. 5:5772-5778.

Berks, B. C., Palmer, T., and Sargent, F. 2003. The Tat protein translocation pathway and its role in microbial physiology. Adv. Microbial Physiol. 47:187-253.

Bertolla, F., Frostegard, A., Brito, B., Nesme, X., and Simonet, P. 1999. During infection of its host, the plant pathogen Ralstonia solanacearum naturally develops a state of competence and exchanges genetic material. Mol. Plant-Microbe Interact. 12:467-472.

Brown, D. G., and Allen, C. 2004. Ralstonia solancearum genes induced during growth in tomato: An inside view of bacterial wilt. Mol. Microbiol. 53:1641-1660.

Buddenhagen, I., and Kelman, A. 1964. Biological and physiological aspects of bacterial wilt caused by Pseudomonas solanacearum. Annu. Rev. Phytopathol. 2:203-230.

Buddenhagen, I., Sequeira, L., and Kelman, A. 1962. Designation of races in Pseudomonas solanacearum. (Abstr.) Phytopathology 52:726.

Buddenhagen, I. W. 1965. The relation of plant-pathogenic bacteria to the soil. Pages 269-284 in: Ecology of Soil Borne Plant Pathogens. K. F. Baker and W. C. Snyder, eds. University of California Press, Berkeley, U.S.A.

Carney, B. F., and Denny, T. P. 1990. A cloned avirulence gene from Pseudomonas solanacearum determines incompatibility on Nicotiana tabacum at the host species level. J. Bacteriol. 172:4836-4843.

Ciampi, L., and Sequeira, L. 1980. Influence of temperature on virulence of race 3 strains of Pseudomonas solanacearum. Am. Potato J. 57:307-317.

Coenye, T., and Vandamme, P. 2003. Simple sequence repeats and compositional bias in the bipartite Ralstonia solanacearum GM11000 genome. BMC Genomics 4:10.

Cunnac, S., Boucher, C., and Genin, S. 2004a. Characterization of the cisacting regulatory element controlling HrpB-mediated activation of the type III secretion system and effector genes in Ralstonia solanacearum. J. Bacteriol. 186:2309-2318.

Cunnac, S., Occhialini, A., Barberis, P., Boucher, C., and Genin, S. 2004b. Inventory and functional analysis of the large Hrp regulon in Ralstonia solanacearum: Identification of novel effector proteins translocated to plant host cells through the type III secretion system. Mol. Microbiol. 53:115-28.

Dilks, K., Rose, R. W., Hartmann, E., and Pohlschroder, M. 2003. Prokaryotic utilization of the twin-arginine translocation pathway: A genomic survey. J. Bacteriol. 185:1478-83.

Elphinstone, J. G. 1996. Survival and possibilities for extinction of Pseudomonas solanacearum (Smith) Smith in cool climates. Potato Res. 39:403-410.

Elphinstone, J. G. 2005. The current bacterial wilt situation: A global overview. Pages 9-28 in: Bacterial Wilt: The Disease and the Ralstonia solanacearum Species Complex. C. Allen, P. Prior, and A. C. Hayward, eds. American Phytopathological Society Press, St. Paul, MN, U.S.A.

Elphinstone, J. G., Stanford, H., and Stead, D. E. 1998. Detection of Ralstonia solanacearum in potato tubers, Solanum dulcamara and associated irrigation water. Pages 133-139 in: Bacterial Wilt Disease: Molecular and Ecological Aspects. P. Prior, C. Allen, and J. G. Elphinstone, eds. Springer-Verlag, Berlin.

Fegan, M., and Prior, P. 2005. How complex is the Ralstonia solanacearum species complex? Pages 449-461 in: Bacterial Wilt: The Disease and the Ralstonia solanacearum Species Complex. C. Allen, P. Prior, and A. C. Hayward, eds. American Phytopathological Society Press, St. Paul, MN, U.S.A

Fegan, M., Hollway, G., Hayward, A. C., and Timmis, J. 1998a. Development of a diagnostic test based upon the polymerase chain reaction (PCR) to identify strains of Ralstonia solanacearum exhibiting the biovar 2 genotype. Pages 34-43 in: Bacterial Wilt Disease: Molecular and Ecological Aspects. P. Prior, C. Allen, and J. G. Elphinstone, eds. Springer-Verlag, Berlin.

Fegan, M., Taghavi, M., Sly, L. I., and Hayward, A. C. 1998b. Phylogeny, diversity, and molecular diagnostics of Ralstonia solanacearum. Pages 19-33 in: Bacterial Wilt Disease: Molecular and Ecological Aspects. P. Prior, C. Allen, and J. G. Elphinstone, eds. Springer-Verlag, Berlin.

Gordon, D., Abajian, C., and Green, P. 1998. Consed: A graphical tool for sequence finishing. Genome Res. 8:195-202.

Greenberg, J. T., and Vinatzer, B.A. 2003. Identifying type III effectors of plant pathogens and analyzing their interaction with plant cells. Curr. Opin. Microbiol. 6:20-28.

Haas, B. J., Delcher, A. L., Wortman, J. R., and Salzberg, S. L. 2004. DAGchainer: A tool for mining segmental genome duplications and synteny. Bioinformatics 20:3643-3646

Hayward, A. C. 1964. Characteristics of Pseudomonas solanacearum. J. Appl. Bacteriol. 27:265-277. 
Hayward, A. C. 1991. Biology and epidemiology of bacterial wilt caused by Pseudomonas solanacearum. Annu. Rev. Phytopathol. 29:65-87.

Hayward, A. C. 1994. Systematics and phylogeny of Pseudomonas solanacearum and related bacteria. Pages 123-135 in: Bacterial Wilt: The Disease and its Causative Agent, Pseudomonas solanacearum. A. C. Hayward and G. L. Hartman, eds. CAB International, Wallingford, U.K.

He, L. Y., Sequeira, L., and Kellman, A. 1983. Characteristics of strains of Pseudomonas solanacearum from China. Plant Dis. 67:1357-61.

Hohn, B., and Collins, J. 1980. A small cosmid for efficient cloning of large DNA fragments. Gene 11:291-98.

Janse, J. D., Beld, H. E. v. d., Elphinstone, J., Simpkins, S., Tjou-Tam-Sin, N. A. A., and Vaerenbergh, J. V. 2004. Introduction to Europe of Ralstonia solanacearum biovar 2, race 3 in Pelargonium zonale cuttings. J. Plant Pathol. 86:147-155.

Kachlany, S. C., Planet, P. J., DeSalle, R., Fine, D. H., and Figurski, D. H. 2001. Genes for tight adherence of Actinobacillus actinomycetemcomitans: From plaque to plague to pond scum. Trends Microbiol. 9:429-437.

Kim, S. H., Olson, T. N., Schaad, N. W., and Moorman, G. W. 2003. Ralstonia solanacearum Race 3, biovar 2, the causal agent of brown rot of potato, identified in geranium in Pennsylvania, Delaware, and Connecticut. Plant Dis. 87:450.

Kovach, M. E., Phillips, R. W., Elzer, P. H., Roop, R. M., and Peterson, K. M. 1994. pBBR1MCS: A broad-host-range cloning vector. BioTechniques 16:800-802.

Kurtz, S., Phillippy, A., Delcher, A. L., Smoot, M., Shumway, M., Antonescu, C. and Salzberg, S. L. 2004. Versatile and open software for comparing large genomes. Genome Biol. 5:R12.

Lambert, C. D. 2002. Agricultural Bioterrorism Protection Act of 2002: Possession, use, and transfer of biological agents and toxins; interim final rule. (7 CFR Part 331). Fed. Regist. 67 (240):76908-76938.

Lander, E. S., and Waterman, M. S. 1988. Genomic mapping by fingerprinting random clones: A mathematical analysis. Genomics 2:231-239.

Liu, H., Kang, Y., Genin, S., Schell, M. A., and Denny, T. P. 2001. Twitching motility of Ralstonia solanacearum requires a type IV pilus system. Microbiology 147:3215-3229.

Lozano, J. C., and Sequeira, L. 1970. Differentiation of races of Pseudomonas solanacearum by a leaf infiltration technique. Phytopathology 60:833-838

Mukaihara, T., Tamura, N., Murata, Y., and Iwabuchi, M. 2004. Genetic screening of Hrp type III-related pathogenicity genes controlled by the HrpB transcriptional activator in Ralstonia solanacearum. Mol. Microbiol. 54:863-875.

Newman, K. L., Almeida, R. P., Purcell, A. H., and Lindow, S. E. 2003. Use of a green fluorescent strain for analysis of Xylella fastidiosa colonization of Vitis vinifera. Appl. Environ. Microbiol. 69:7319-7327.

Overbeek, R., Larsen, N., Walunas, T., D'Souza, M., Pusch, G., Selkov, E., Liolios, K., Joukov, V., Kaznadzey, D., Anderson, I., Bhattacharyya, A., Burd, H., Gardner, W., Hanke, P., Kapatral, V., Mikhailova, N., Vasieva, O, Osterman, A., Vonstein, V., Fonstein, M., Ivanova, N., and Kyrpides, N. 2003. The ERGO (TM) genome analysis and discovery system. Nucleic Acids Res. 31:164-171.

Prior, P., Allen, C., and Elphinstone, J. 1998. Bacterial Wilt Disease: Molecular and Ecological Aspects. Springer Verlag, Berlin.

Prior, P., and Fegan, M. Recent developments in the phylogeny and classification of Ralstonia solanacearum. Acta Hortic. In press.

Robertson, A. E., Wechter, W. P., Denny, T. P. Fortnum, B. A., and Kluepfel, D. A. 2004. Relationship between avirulence gene (avrA) diversity in Ralstonia solanacearum and bacterial wilt incidence. Mol. Plant-Microbe Interact. 17:1376-1384.

Salanoubat, M., Genin, S., Artiguenave, F., Gouzy, J., Mangenot, S., Arlat, M., Billault, A., Brottier, P., Camus, J., Cattolico, L., Chandler, M.,
Choisne, N., Claudel-Renard, C., Cunnac, S., Demange, N., Gaspin, C. Lavie, M., Moisan, A., Robert, C., Saurin, W., Schiex, T., Siguier, P., Thebault, P., Whalen, M., Wincker, P., Levy, M., Weissenbach, J., and Boucher, C. A. 2002. Genome sequence of the plant pathogen Ralstonia solanacearum. Nature 415:497-502.

Sambrook, J., and Russell, D. W. 2001. Molecular Cloning: A Laboratory Manual, 3rd ed. Cold Spring Harbor Laboratory Press, Cold Spring Harbor, NY, U.S.A.

Sandkvist, M. 2001. Biology of type II secretion. Mol. Microbiol. 40:271283.

Schell, M. A. 2000. Control of virulence and pathogenicity genes of Ralstonia solanacearum by an elaborate sensory network. Annu. Rev. Phytopathol. 38:263-292.

Sequeira, L., and Averre, C. W., III. 1961. Distribution and pathogenicity of strains of Pseudomonas solanacearum from virgin soils in Costa Rica. Plant Dis. Rep. 45:435-440.

Strider, D. L., Jones, R. K., and Haygood, R. A. 1981. Southern wilt of geranium caused by Pseudomonas solanacearum. Plant Dis. 65:52-53.

Swanepoel, A. E. 1990. The effect of temperature on the development of wilting and on progeny tuber infection of potatoes inoculated with South-African strains of biovar- 2 and biovar- 3 of Pseudomonas solanacearum. Potato Res. 33:287-290.

Swanson, J. K., Yao, J., Tans-Kersten, J. K., and Allen, C. 2005. Behavior of Ralstonia solanacearum race 3 biovar 2 during latent and active infection of geranium. Phytopathology 95:136-143.

Tans-Kersten, J., Huang, H., and Allen, C. 2001. Ralstonia solanacearum needs motility for invasive virulence on tomato. J. Bacteriol. 183:35973605 .

Thurston, H. D. 1963. Bacterial wilt of potatoes in Columbia. Am. Potato J. 40:381-390.

Tusiime, G., Adipala, E., Opio, F., and Bhagsari, A. S. 1998. Weeds as latent hosts of Ralstonia solanacearum in highland Uganda: Implications to development of an integrated control package for bacterial wilt Pages 413-419 in: Bacterial Wilt Disease: Molecular and Ecological Aspects. P. Prior, C. Allen, and J. G. Elphinstone, eds. Springer-Verlag, Berlin.

van Elsas, J. D., Kastelein, P., Bekkum, P. V., Wolf, J. M. v. d., Vries, P. M., and Overbeek, L. S. 2000. Survival of Ralstonia solanacearum Biovar 2, the causative agent of potato brown rot, in field and microcosm soils in temperate climates. Phytopathology 90:1358-1366.

van Elsas, J. D., Kastelein, P., de Vries, P. M., and Overbeek, L. S. 2001. Effects of ecological factors on the survival and physiology of Ralstonia solanacearum bv. 2 in irrigation water. Can. J. Microbiol. 47:842854.

Villa, J. E., Tsuchiya, K., Horita, M., Opina, N., and Hyakumachi, M 2005. Phylogenetic relationships of Ralstonia solanacearum species complex strains from Asia and other continents based on 16S rDNA, endoglucanase, and $h r p B$ gene sequences. J. Gen. Plant Pathol. 71:3946.

Vinatzer, B. A., Jelenska, J., and Greenberg, J. T. 2005. Bioinformatics correctly identifies many type III secretion substrates in the plant pathogen Pseudomonas syringae and the biocontrol isolate $P$. fluorescens SBW25. Mol. Plant-Microbe Interact. 18: 877-888.

Williamson, L., Hudelson, B. D., and Allen, C. 2002. Ralstonia solanacearum strains isolated from geranium belong to Race 3 and are pathogenic on potato. Plant Dis. 86:987-991

\section{AUTHOR RECOMMENDED INTERNET RESOURCES}

The University of Florida's Interdisciplinary Center for Biotechnology Research (UF/ICBR) Genomics Server: genomics.biotech.ufl.edu 